\title{
Customer oriented determinants of e-CRM success factors
}

\author{
Anas A. Salameh ${ }^{a^{*}}$, Amer Hatamleh ${ }^{b}$, Md Shamimul Azim ${ }^{c}$ and Anas G. Kanaan ${ }^{d}$
}

\begin{abstract}
${ }^{a}$ Department of Management Information Systems, College of Business Administration, Prince Sattam Bin Abdulaziz University, 165 Al-Kharj, 11942, Saudi Arabia

${ }^{b}$ Faculty of Financial \& Sciences, Irbid National University, 2600 Irbid, 21110 Jordan

${ }^{c}$ School of Business Management, Universiti Utara Malaysia, 06010 UUM, Sintok, Kedah, Malaysia

${ }^{d}$ Business \& E-Commerce Department, Faculty of Administrative \& Financial Sciences, University of Petra, 961343 Amman, Jordan

\begin{tabular}{l}
\hline C H R O N I C L E \\
\hline Article history: \\
Received May 5, 2020 \\
Received in revised format June \\
8,2020 \\
Accepted August 12020 \\
Available online \\
August 12020 \\
\hline Keywords: \\
eCRM \\
CRM \\
Customer Satisfaction \\
Customer Profitability \\
Customer trust and \\
Commitment
\end{tabular}

Web based and/or existing e-commerce have changed the traditional view of CRM to the eCRM. Recent studies on eCRM has investigated success factors of e-CRM in different contexts and fields. This paper aims to investigate the effect of customer satisfaction, customer trust and commitment, customer profitability on eCRM in Saudi Arab. This study was designed quantitative cross-sectional questionnaire survey. This quantitative study used questionnaire survey design and 319 respondents were taken into account for analysis procedure. Structural Equation Modelling was applied and SmartPLS tools was used to test the hypotheses. Customer satisfaction, customer profitability, trust and commitment have shown to have positive significant effects on eCRM. Empirical evidence of this study confirmed that from the customer point of view customers satisfaction, customer profitability, customer trust and commitment were the strong predictors of successful eCRM.
\end{abstract}

(C) 2020 by the authors; license Growing Science, Canada.

\section{Introduction}

Customer relationship management (hereafter CRM) is a strategy to develop a relationship and identify the customer needs to create loyal customers. Loyal customers are comparatively profitable to the company. CRM helps companies analyze the behavioral pattern, needs and develops the relationship with customers by providing products and services (Herman, Sulhaini, \& Farida, 2020). CRM allows a company to reduce the cost of marketing to maintain relationship and provides specific products and services to existing customers (Al-Dmour, Algharabat, Khawaja, \& Al-Dmour, 2019; Herman et al., 2020; Roh, Ahn, \& Han, 2005). However recently, web based and/or existing e-commerce have changed the traditional view of CRM to the eCRM. Dramatic changes have happened in many aspects of the existing commerce, including the creation of new companies with new business models, business opportunities and Modern Business Processing Techniques. E e-commerce and/or m-commerce have become an alternative for communications in the areas of sales, marketing and customer support (AlSondos \& Salameh, 2020; Salameh \& Hassan, 2015). These changes have created the competitive advantage for the companies in this digital era. Advances are taking place notoriously in the environment of marketing through the last few years. Information technology has supported various new progress in the business and marketing fields. The impacts of IT in management and marketing areas have underlined the importance value of reconstructing new arranging for marketing that makes website technology. Many studies have found that various corporations have switched their attention to how companies can remain a long-lasting and positive relationship with customers and how to develop loyalty of consumers. Thus, the policies of firms have moved towards strategies of customer oriented. Critical factors such

\footnotetext{
* Corresponding author Tel.: +966548172138

E-mail address: a.salameh@psau.edu.sa (A. A. Salameh)

(C) 2020 by the authors; licensee Growing Science.

doi: $10.5267 /$ j.uscm.2020.8.001
} 
as giving extra services, understanding the requirements of the consumers are described as factors to determine the fate of organizations (Wayland \& Cole, 1997).

Today, many institutions and other service supplier realize the effect of electronic customer relationship management (eCRM) and its potential to help them acquire new consumers and keep existing ones and increase their lifetime value. CRM is a business policy that helps organizations identify the most valuable consumers and gives attention and time to develop relationships with those consumers by individualized repricing, marketing, and customized service-all presented by different sales channels. An essential and efficient advantage of web-based E-CRM is the volume of available information to consumers browsing. Meanwhile, this can be seen as a deficiency of web-based E-CRM. The expectation of web-based ECRM in future is totally in the hands of one to one website. The rush to execute E-CRM systems is on. Companies want to deliver the huge benefits of a high return on investments (ROI) progresses in customer loyalty, etc. (Fjermestad \& Romano, 2003).

However, web-based and/or e-CRM have gained attention in academia and practice. Recent focus on eCRM and studies has investigated success factors of e-CRM in different contexts and fields. For instance, in Jordanian banking sector AlDmour et al. (2019) determine the eCRM success factors and its effect on customers' satisfaction and trust and retention. Whereas, Roh et al. (2005) investigated the eCRM success factors and its effect only on customer satisfaction. One of the most important factors which is customer profitability is not prioritized in these studies. In addition to that, trust with the customer retention had been investigated, although if the customers have trust but not committed then the goal of eCRM will be in vain. To fill this gap, therefore, in this study we have focused and investigated customer trust and commitment, customer satisfaction along with the customer profitability effect on eCRM.

\section{Literature and Hypotheses of the Study}

\subsection{Traditional Customer Relationship Management (CRM) to e-CRM}

The significant goal of CRM can be described as managing and understanding consumers in a proper way in order to increase loyalty and profitability. The idea has extended a continuous evolution and marketing methods to its present state, which is different from the prior efforts by adding importance to "reshaping relations between consumers and corporations rather than trying to just sell” (Fjermestad \& Romano, 2003; Tan, Yen, \& Fang, 2002). In current years CRM has gone through stages of technological changes. Bull (2003) explained that while CRM is a business process based on the efficient consumer's relationships management, another very significant aspect of CRM is its technological orientation. Furthermore, Chen and Popovich (2003) explained that CRM is a combined method of managing consumer relationships by combining three important elements: people, technology and process. Moreover, the opportunities of customization assist to create connections with stakeholders depending on the emotional way (Ragins \& Greco, 2003). Hence, as Winer (2001) clearly states that the web environment clearly has the ability to build more satisfying relationships with consumers than the offline environment. The internet presents such a hopeful field for CRM implementations, benefit in E-CRM can be gained only by a well-designed plan that suits the quality of this environment. Hence, it is important to estimate the E-CRM activities performance of internet and evaluate how efficiently they profit from the CRM programs.

\subsection{E-CRM and Success Factors}

The eCRM was conceptualized as "a combination of traditional CRM, with e-business marketplace applications"(Miremadi, Ghalamakri, \& Ramezani, 2012). In other study, eCRM has been conceptualized as the combination of hardware software, applications and management commitment (Lederer, Maupin, Sena, \& Zhuang, 2000; Miremadi et al., 2012). E-CRM has developed in recent years to become the primary strategy that gives a combination of diverse activities for understanding, predicting, and satisfying customer needs (Harrigan, Ramsey, \& Ibbotson, 2012; Herman et al., 2020). Based on Sheng (2002), the main purposes of E-CRM are the gaining and retention of consumers, driving financial benefits for bottom-line. The newest advancements in Internet-based technology assisted the emergence of E-CRM, allowing many innovations in managing relations, inter-organizational collaboration and supply chain management (Ahani, Rahim, \& Nilashi, 2017; Hadaya \& Cassivi, 2009; Usman, Jalal, \& Musa, 2012).

Romano and Fjermestad (2003) propose that successful E-CRM demands to attract and retain economically worthy consumers while dropping economically priceless ones. Winer (2001) states that E-CRM is the fashionable "mantra" of marketing. The old focus of marketing was the attainment of new consumers; despite, this has moved to consumer retention (Gronroos, 1994). Building relationship and management have become center principles of contemporary marketing methods (Baran \& Galka, 2016; Dwyer, Schurr, \& Oh, 1987).

\subsection{The Relationship between Customer Satisfaction and E-CRM}

Hansemark and Albinsson (2004) explained satisfaction as an overall consumer reaction towards a service giver, or the distinction between consumer perception and consumer expectation about concerning the satisfaction of any needs wants desire or aims. Oliver (1981) explained satisfaction "as an entirety of the psychical situation that results concerning 
consumers expectations". Many studies have asserted that different factors afford on the customer satisfaction, these involve kindness, competing prices, competent and helpful consumers, courteousness, competing prices, quality of service, good value, and fast service (Hokanson, 1995). Service quality is important and has positive effect on customer satisfaction (Salameh, Ahmad, Zulhumadi, \& Abubakar, 2018)

Chen and Chuang (2008) observed that the opinion of the consumer is one of the essential features that assist to manage and enhance consumer satisfaction. Consequently, as organization investigate efficient methods to measure consumer relationships, many have shifted to the traditional mechanism of consumer satisfaction monitoring that historically was practiced for knowing customer thoughts and perception of services and goods. An extra positive relationship is found between satisfaction and the period time of the relationships.

Efficient E-CRM implementation can bring many tangible and intangible benefits to businesses. Xu and Walton (2005) in their research discussed the following main benefits of performing E-CRM: enhancing consumer satisfaction, maintaining existing consumers, giving imperative information, and enhancing consumer lifetime value. Ryals and Knox (2001) discovered that E-CRM applications help in decreasing operational costs, increase service delivery, profitability, and improve consumer satisfaction, retention, and loyalty.

E-CRM has become a vitally important, it allows organizations to customize their offerings for each consumer to satisfy each individual tastes and needs, and to promote the processing of consumer orders (Ahani et al., 2017; Al-Dmour et al., 2019; Doherty \& Lockett, 2007; Herman et al., 2020; Rahimi \& Kozak, 2017). Organizations can gather and combine vital amounts of information about different channels. Moreover, eCRM can be inspected as an opportunity for the organization to use the gathered information to enhance both relationship with customers and the quality of their services (Alzoubi, Alshurideh, Kurdi, \& Inairat, 2020; Kasim \& Minai, 2009) which will lead to higher levels of online customer satisfaction (Alzoubi et al., 2020; Giao, Vuong, \& Quan, 2020). Therefore, in this study, we hypothesized as follows:

$\mathrm{H}_{1}$ : Customers satisfaction has considered as one of the success factor and positive effect on eCRM.

\subsection{The Relationship between Customer Profitability and E-CRM}

Consumer profitability can be defined as the difference between cost and gain. Estimating the consumer donation margin needs comprehensive analysis including elements such as goods costs, expenses to obtain, costs to complete and cost to preserve. In recent years organization are facing a completely changed landscape, the manner of building a relationship between consumers and firms can simply improve lifetime value and boosts profitability (Nguyen \& Mutum, 2012).

In these circumstances, E-CRM is not just a tool but comparatively more a policy for efficient consumer relationship management and measurement for consumer profitability in a competing market. The combination of e-commerce and CRM lies in the firm's handling all perspectives of relationships to improve consumers loyalty and maintenance as well as a firm`s profitability (Chong, Shafaghi, \& Tan, 2011). We, therefore, in this study develop the following hypothesis:

$\mathrm{H}_{2}$ : Customers profitability has considered as one of the success factor and positive effect on eCRM.

\subsection{The Relationship between Trust and Commitment and E-CRM}

According to Tam and Wong (2001) and Sánchez-Garcia, Moliner-Tena, Callarisa-Fiol, and Rodríguez-Artola (2007), customer trust and commitment are two factors that contribute to relationship quality. Trust is the level of belief and readiness in the mind of a consumer to deal with the organization. Relationship quality can be described as how well consumers recognize the accomplishment of their expectations, desires, projections, and aims concerning the entire relationship with the firm (Sivaraks, Krairit, \& Tang, 2011). Trust is a sense of security based on the faith that desirable and positive intentions across well-being are on the list, taking benefit of the vulnerability for others(Al-Refaie, Tahat, \& Bata, 2014; Morgan \& Hunt, 1994). Significant results of relations based on the trust constitute the following characteristics:

Enhanced cooperation. Trust can decrease the feelings of doubt and risk (Dwyer et al., 1987).

Enhanced commitment. Trust enhance commitment, though, consumers are careful to trustworthy partners (Morgan \& Hunt, 1994; Nguyen \& Mutum, 2012; Selnes, 1998).

Relationship continuance. Trust promotes investment in long-term relationships by obtaining future business rather than short-term earnings (Ballester \& Alemán, 2001; Morgan \& Hunt, 1994).

Crosby, Evans, and Cowles (1990) suggested that e-CRM can improve relationship quality. Commonly, consumers with a powerful relationship with the company have a more positive perception of the enterprise's CRM/e-CRM actions (Garbarino \& Johnson, 1999). Trust is an important predictor of e-commerce receiving (Suh \& Han, 2003). In addition, customer trust 
is one of the best factors that impact e-CRM performance. The concept of trust creates the dependence of a strong and sustainable connection with a consumer and significantly defines the consumer's expected capabilities and behavior with the organization (Berry \& Parasuraman, 2004; Greenberg, 2010). Trust relates to the beliefs, attitudes, passions of users that appear when they feel that their provider is reliable and acts for their interest upon (Greenberg, 2010; Patrick, 2002). Whereas, consumer commitment is a significant element that distinguishes social from economic change(Cook \& Emerson, 1978). Customer trust and commitment is a different factor that affects the performance of e-CRM. In marketing research, consumer commitment is considered to be a crucial part of the improvement of relationships (Al-Dmour et al., 2019; Dwyer et al., 1987; Ziaullah, Feng, \& Akhter, 2014). With the discussion above, the relationship between trust and commitment with E-CRM have been hypothesized as follows:

$\mathrm{H}_{3}$ : Customers profitability has considered as one of the success factor and positive effect on eCRM.

\section{Method}

This cross-sectional and practical analytical research, using SEM-PLS, investigated the effects of customer satisfaction, customer trust and commitment, customer profitability on eCRM success. Following the Fig. 1 presents the hypothesized model of the study. This cross-sectional quantitative research used questionnaire survey method. Customer satisfaction measured 4 items and eCRM measured by 12 items adapted from (Roh et al., 2005). The scale customer trust and commitment were adapted and consisted of four items (Lai, Lee, \& Hsu, 2009). Customer profitability scale was measured using four items and adapted (Pezeshki, Mousavi, \& Rakowski, 2005). Questionnaire were distributed to the 385 respondents (we based and/online customers) in Saudi Arabia. SPSS 24 and SmartPLS 3 were used to analyze the collected data. Out of the 385 questionnaires that were randomly distributed among customers those shops online and users in Saudi Arab. A total of 336 filled questionnaires were returned. However, 17 of the questionnaires were not completed accordingly. Data were analyzed in three steps; descriptive statistics, measurement model assessment and structural model assessment. Descriptive statistics of the variables was assessed by SPSS 24. Table 1 shows the result of the descriptive statistics of the study variables.

Table 1

Descriptive Statistics

\begin{tabular}{cccccc}
\hline Constructs & N & Minimum & Maximum & Mean & Std. Deviation \\
\hline Customer Satisfaction & 319 & 1.00 & 5.00 & 3.6513 & 0.9830 \\
Customer Profitability & 319 & 1.00 & 5.00 & 3.6716 & 0.9804 \\
Trust and Commitment & 319 & 1.00 & 5.00 & 3.5439 & 3.6439 \\
eCRM & 319 & 1.00 & 5.00 & 0.9827 \\
\hline
\end{tabular}

As shown in Table 1, highest mean value consists of customer profitability (3.6716), followed by customer satisfaction (3.6513), eCRM (3.6439) and trust and commitment (3.5439). Minimum values for all variables are 1.00 and maximum is 5.00 as this study is using five-point Likert type scale for getting the opinions from the respondents about four variables of the study. Highest standard deviation is conceded for trust and commitment (1.0296), followed by customer satisfaction (0.9830), eCRM (0.9827) and customer profitability (0.9804).

\section{Result and Findings}

\subsection{Measurement Model}

In the measurement model of the study, the outer loadings/factor loadings are good enough to fit into the construct (Figure 1). Outer loadings of the study variable (customer satisfaction, customer profitability, trust and commitment, and eCRM) are fallen within the threshold 0.40 to 0.70 value suggested (Hair, Hollingsworth, Randolph, \& Chong, 2017). All indicators loadings for the constructs are above 0.40 .

Table 2

Construct Reliability and Validity

\begin{tabular}{lcccc}
\hline Constructs & Cronbach's Alpha & rho_A & $\begin{array}{c}\text { Composite } \\
\text { Reliability }\end{array}$ & $\begin{array}{c}\text { Average Variance Extracted } \\
\text { (AVE) }\end{array}$ \\
\hline Customer Satisfaction & 0.828 & 0.835 & 0.885 & 0.659 \\
Customer Profitability & 0.836 & 0.847 & 0.891 & 0.673 \\
Trust and Commitment & 0.830 & 0.834 & 0.887 & 0.643 \\
eCRM & 0.934 & 0.938 & 0.943 \\
\hline
\end{tabular}

Table 3

Heterotrait-Monotrait Ratio (HTMT)

\begin{tabular}{lccc}
\hline Constructs & Customer satisfaction & Customer profitability & Trust \& Commitment \\
\hline Customer Satisfaction & & & eCRM \\
Customer Profitability & 0.651 & & 0.642 \\
Trust and Commitment & 0.598 & 0.498 & 0.727 \\
eCRM & 0.715 & & \\
\hline
\end{tabular}




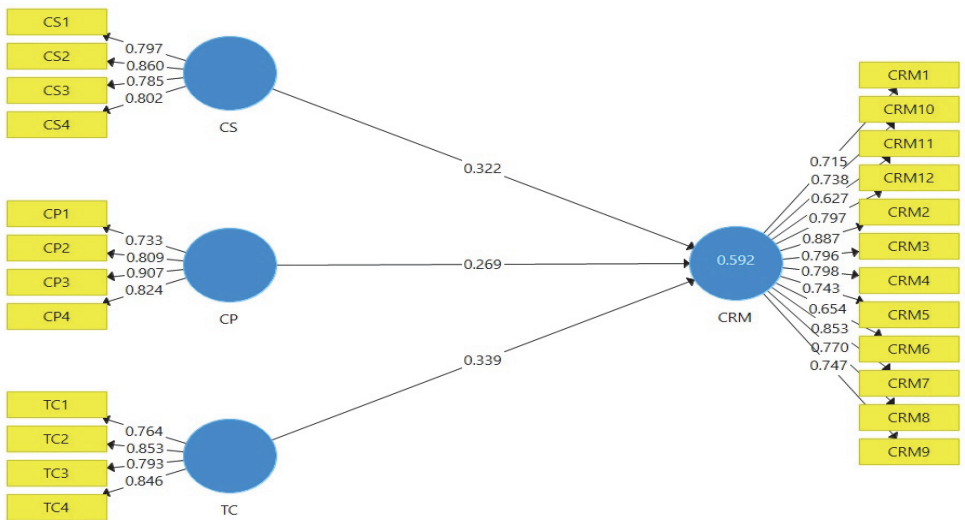

Fig. 1. Measurement model

Table 4

Inner VIF Values

\begin{tabular}{lc}
\hline Constructs & eCRM \\
\hline Customer Satisfaction & 1.556 \\
Customer Profitability & 1.630 \\
Trust and Commitment & 1.529 \\
\hline
\end{tabular}

As shown in Table 2, Cornbach's Alpha of customers satisfaction 0.828 , for customer profitability 0.836 , for customer trust and commitment 0.830 and for eCRM 0.934, which are in acceptable range. As far the requirement of the Structural Equation Modelling, average variance extracted for all constructs are greater than 0.5 which indicates a strong construct to build up statistical relationship. The recent trend of SEM, heterotrait-monotrait (HTMT) ratio were conducted to determine the discriminant validity and found that all values of the constructs (Table 3) are below the threshold value of 0.90 (Hair et al., 2017; Henseler et al., 2014). VIF is calculated as "1/Tolerance". As a rule of thumb, the value of VIF must be 5 or lower (i.e., Tolerance level of 0.2 or higher) to avoid the multicollinearity issues among the variables (Hair, Ringle, \& Sarstedt, 2011). Before proceeding to the structural assessment of the inner model VIF Values were assessed and found that (Table 4) there is no multicollinearity issue.

\subsection{Structural Model Assessment and Hypothesis Testing}

The diagram in Fig. 2 is shown to demonstrate structural model of the study. T-values of the model are showing high efficiency in the construct. The influence of independent variable to dependent variable is positively significant. Following in Table 5 shows the result of direct effect of structural model of this study.

Table 5

Results of Structural Model (direct effect) of the study

\begin{tabular}{lcccc}
\hline Variable & Coefficient & t-value & p value & Significance \\
\hline Customer Satisfaction $\rightarrow$ eCRM & 0.322 & 5.643 & 0.000 & Yes \\
Customer Profitability $\rightarrow$ eCRM & 0.269 & 4.470 & 0.000 & Yes \\
Trust and Commitment $\rightarrow$ eCRM & 0.339 & 6.241 & 0.000 & yes \\
\hline
\end{tabular}

Table 6

Results of Structural Model effect size and $\mathrm{R}^{2}$

\begin{tabular}{lcc}
\hline Variable & $f^{2}$ & $\mathrm{R}^{2}(\mathrm{eCRM})$ \\
\hline Customer Satisfaction & 0.164 & 0.592 \\
Customer Profitability & 0.109 & 0.184 \\
Trust and Commitment & & 0.18 \\
\hline
\end{tabular}

As shown in Table 5, the direct effect of exogenous variables on endogenous are presented. Customer satisfaction with $\beta=$ $0.322, \mathrm{t}=5.643, \mathrm{p}=0.000$ has significant effect on eCRM. Customer profitability with $\beta=0.269, \mathrm{t}=4.470, \mathrm{p}=0.000$ has positive effect on eCRM. Customer trust and commitment with $\beta=0.339, \mathrm{t}=6.241, \mathrm{p}=0.000$ has significant effect on eCRM. The effect size (Table 6$)$ of customer satisfaction $\left(f^{2}=0.164\right)$, customer trust and commitment $\left(f^{2=} 0.184\right)$ and it is considerable medium effect on eCRM. However, customer profitability $f^{2=} 0.109$ has small effect on eCRM. This assessment of model is the direct effect of the variables. As a rule of thumb, values higher than $0.02,0.15$ and 0.35 illustrate small, medium and large $\mathrm{f}^{2}$ effect sizes (Cohen, 1988). More importantly the $\mathrm{R}^{2}=0.52$, is a function of the number of predictor 
(customer satisfaction, customer profitability and customer trust and commitment) is medium for this study (Hair, Risher, Sarstedt, \& Ringle, 2019).

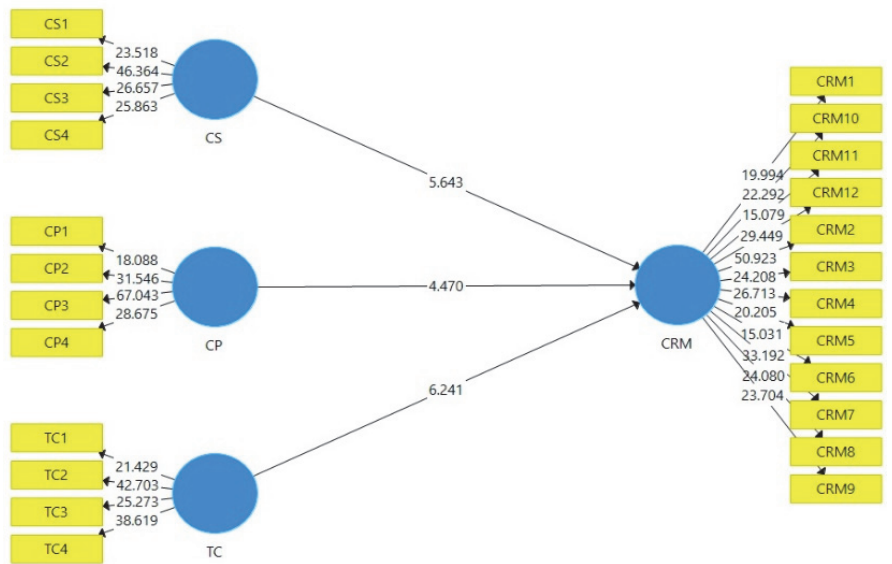

Fig. 2. Structural Model of the study

\section{Discussion, Conclusion and Implications}

Electronic customer relationship management (e-CRM) is an investment for many organizations and the goal of this study is to gain a sufficient understanding of the benefits of eCRM to consumers and corporation. This study found that customer satisfaction (H1, accepted) significantly effects eCRM in the context of Saudi Arab. Similar finding Xu and Walton (2005) asserted that performing eCRM was to enhance consumer satisfaction. In line with finding of this study Ryals and Knox (2001) found that eCRM and customer satisfaction are related and through decreasing operational costs and providing effective service delivery improve consumer satisfaction. Customer profitability, found in this study, has positive effect on eCRM and is in accordance with previous finding of Babatunde and Ajayi (2010). Customer profitability and eCRM are positively related to keep long-term relationships of company and customers (Rollins \& Halinen, 2005). Ryals and Knox (2001) in their study suggested that eCRM applications help in decreasing operational costs and speed the delivery. This which in turn can decrease the price of a product and customer get the benefit and profit. Customer trust and commitment positively effect successful eCRM and this finding is similar with Tam and Wong (2001) and Sánchez-Garcia et al. (2007), customer trust and commitment are two factors that contribute to relationship quality. Customer trust and commitment are the key predictor of retaining a loyal customer to the organization. Al-Dmour et al. (2019) and this study suggest that the eCRM is one of the success factors in customers' trust and commitment to retain loyal customers. Internet-based corporations require to have a competitive advantage. One-way of developing competitive advantage is to bring and attract more consumers and heighten consumer retention, by improving long-term relationships between the consumers and sellers. Few empirical studies have been carried on that link among electronic customer relationship management and customer profitability, customer satisfaction, customer trust and commitment and loyalty within e-commerce and internet. This study sheds the light to the eCRM literature and fills the gap that the customer profitability has positive effect on eCRM. In addition, this study has taken account the customer point of view to determine the customer profitability as a predictor of successful eCRM. Moreover, this study considers first in author knowledge that provide the empirical evidence of the combination of customer satisfaction, customer profitability, customer trust and commitment for eCRM.

This study, therefore, contributes to the e-CRM literature to improve profitability, consumer trust and commitment, consumer satisfaction which in turn leads to customer retention, and acquisition. However, the study has some limitations for instance, more larger sample size can be attained. Future studies for sectoral comparisons will give more details and insight into the eCRM success, which can be made with respect to the success and achievement of e-CRM implementations. Finally, along with the customer focus measuring organizational factors for example, management commitment and top management support to predict the success of e-CRM as suggested by Chang et al. (2009).

\section{References}

Ahani, A., Rahim, N. Z. A., \& Nilashi, M. (2017). Forecasting social CRM adoption in SMEs: A combined SEM-neural network method. Computers in Human Behavior, 75, 560-578.

Al-Dmour, H. H., Algharabat, R. S., Khawaja, R., \& Al-Dmour, R. H. (2019). Investigating the impact of ECRM success factors on business performance. Asia Pacific Journal of Marketing and Logistics.

Al-Refaie, A., Tahat, M. D. A., \& Bata, N. (2014). CRM/e-CRM effects on banks performance and customer-bank relationship quality. International Journal of Enterprise Information Systems (IJEIS), 10(2), 62-80.

AlSondos, I., \& Salameh, A. (2020). The effect of system quality and service quality toward using m-commerce service, based on consumer perspective. Management Science Letters, 10(11), 2589-2596. 
Alzoubi, H., Alshurideh, M., Kurdi, B., \& Inairat, M. (2020). Do perceived service value, quality, price fairness and service recovery shape customer satisfaction and delight? A practical study in the service telecommunication context. Uncertain Supply Chain Management, 8(3), 579-588.

Babatunde, B., \& Ajayi, E. (2010). The relevance of customer relationship management in the nigerian banking industry (A case study of Intercontinental Bank Plc). Information Management, 12, 108.

Ballester, E., \& Alemán, J. L. (2001). Brand trust in the context of consumer loyalty. European Journal of marketing, $35(11 / 12), 1238-1258$.

Baran, R. J., \& Galka, R. J. (2016). Customer Relationship Management: the foundation of contemporary marketing strategy: Taylor \& Francis.

Berry, L. L., \& Parasuraman, A. (2004). Marketing services: Competing through quality: Simon and Schuster.

Bull, C. (2003). Strategic issues in customer relationship management (CRM) implementation. Business Process Management Journal, 9(5), 592-602.

Chang, T.-M., Liao, L.-L., \& Hsiao, W.-F. (2005). An empirical study on the e-CRM performance influence model for service sectors in Taiwan. Paper presented at the 2005 IEEE International Conference on e-Technology, e-Commerce and e-Service.

Chen, C. C., \& Chuang, M. C. (2008). Integrating the Kano model into a robust design approach to enhance customer satisfaction with product design. International Journal of Production Economics, 114(2), 667-681.

Chen, I. J., \& Popovich, K. (2003). Understanding customer relationship management (CRM). Business Process Management Journal, 9(5), 672-688.

Chong, W. K., Shafaghi, M., \& Tan, B. L. (2011). Development of a business-to-business critical success factors (B2B CSFs) framework for Chinese SMEs. Marketing Intelligence \& Planning, 29(5), 517-533.

Cohen, J. (1988). Statistical power analysis for the behavioral sciences New York. NY: Academic.

Cook, K. S., \& Emerson, R. M. (1978). Power, equity and commitment in exchange networks. American Sociological Review, 43(5), 721-739.

Crosby, L. A., Evans, K. R., \& Cowles, D. (1990). Relationship quality in services selling: an interpersonal influence perspective. Journal of Marketing, 54(3), 68-81.

Doherty, N. F., \& Lockett, N. J. (2007). Closing the gap between the expectations of relationship marketing and the reality of E-CRM. International Journal of E-Business Research, 3(2).

Dwyer, F. R., Schurr, P. H., \& Oh, S. (1987). Developing buyer-seller relationships. Journal of Marketing, 51(2), 11-27.

Fjermestad, J., \& Romano, N. C. (2003). Electronic customer relationship management. Business Process Management Journal, 9(5), 572-591.

Garbarino, E., \& Johnson, M. S. (1999). The different roles of satisfaction, trust, and commitment in customer relationships. Journal of Marketing, 63(2), 70-87.

Giao, H., Vuong, B., \& Quan, T. (2020). The influence of website quality on consumer's e-loyalty through the mediating role of e-trust and e-satisfaction: An evidence from online shopping in Vietnam. Uncertain Supply Chain Management, $8(2), 351-370$.

Greenberg, P. (2010). The impact of CRM 2.0 on customer insight. Journal of Business \& Industrial Marketing, 25(6), 410419.

Gronroos, C. (1994). From marketing mix to relationship marketing: towards a paradigm shift in marketing. Asia-Australia Marketing Journal, 2(1), 9-29.

Hadaya, P., \& Cassivi, L. (2009). Collaborative e-product development and product innovation in a demand-driven network: the moderating role of eCRM. Electronic Markets, 19(2-3), 71-87.

Hair, J. f., Hollingsworth, C. L., Randolph, A. B., \& Chong, A. Y. L. (2017). An updated and expanded assessment of PLS$\mathrm{SEM}$ in information systems research. Industrial management \& data systems.

Hair, J. f., Ringle, C. M., \& Sarstedt, M. (2011). PLS-SEM: Indeed a silver bullet. Journal of Marketing theory and Practice, 19(2), 139-152.

Hair, J. f., Risher, J. J., Sarstedt, M., \& Ringle, C. M. (2019). When to use and how to report the results of PLS-SEM. European Business Review, 31(1), 2-24.

Hansemark, O. C., \& Albinsson, M. (2004). Customer satisfaction and retention: the experiences of individual employees. Managing Service Quality: An International Journal.

Harrigan, P., Ramsey, E., \& Ibbotson, P. (2012). Exploring and explaining SME marketing: investigating e-CRM using a mixed methods approach. Journal of Strategic Marketing, 20(2), 127-163.

Henseler, J., Dijkstra, T. K., Sarstedt, M., Ringle, C. M., Diamantopoulos, A., Straub, D. W., . . Calantone, R. J. (2014). Common beliefs and reality about PLS: Comments on Rönkkö and Evermann (2013). Organizational research methods, $17(2), 182-209$.

Herman, L. E., Sulhaini, S., \& Farida, N. (2020). Electronic Customer Relationship Management and Company Performance: Exploring the Product Innovativeness Development. Journal of Relationship Marketing, 1-19.

Hokanson, S. (1995). The deeper you analyze, the more you satisfy customers. Marketing News, 29(1), 16-16.

Kasim, A., \& Minai, B. (2009). Linking CRM strategy, customer performance measures and performance in the hotel industry. International Journal of Economics and Management, 3(2), 297-316.

Kımıloğlu, H., \& Zaralı, H. (2009). What signifies success in e-CRM? Marketing Intelligence \& Planning, 27(2), $246-267$.

Lai, J., Lee, G., \& Hsu, W. (2009). The influence of partner's trust-commitment relationship on electronic commerce strategic planning. Management Decision, 47(3), 491-507. 
Lederer, A. L., Maupin, D. J., Sena, M. P., \& Zhuang, Y. (2000). The technology acceptance model and the World Wide Web. Decision support systems, 29(3), 269-282.

Miremadi, A., Ghalamakri, S., \& Ramezani, A. (2012). Challenges in trust and security by implementation of E-CRM among banks and financial institution: a case study of e-banking in Iran. International Journal of Information Science and Management (IJISM), 99-118.

Morgan, R. M., \& Hunt, S. D. (1994). The commitment-trust theory of relationship marketing. Journal of marketing, 58(3), 20-38.

Nguyen, B., \& Mutum, D. S. (2012). A review of customer relationship management: successes, advances, pitfalls and futures. Business Process Management Journal.

Oliver, R. L. (1981). Measurement and evaluation of satisfaction processes in retail settings. Journal of Retailing, 7(3), 2548.

Patrick, A. S. (2002). Building trustworthy software agents. IEEE Internet Computing, 6(6), 46-53.

Pezeshki, V., Mousavi, A., \& Rakowski, R. T. (2005). Profitability through customer relationship marketing. Paper presented at the Proceedings of the International Conference on Computer and Industrial Management, ICIM, October.

Ragins, E. J., \& Greco, A. J. (2003). Customer relationship management and e-business: more than a software solution. Review of Business, 24(1), 25.

Rahimi, R., \& Kozak, M. (2017). Impact of customer relationship management on customer satisfaction: The case of a budget hotel chain. Journal of Travel \& Tourism Marketing, 34(1), 40-51.

Roh, T. H., Ahn, C. K., \& Han, I. (2005). The priority factor model for customer relationship management system success. Expert systems with applications, 28(4), 641-654.

Rollins, M., \& Halinen, A. (2005). Customer knowledge management competence: Towards a theoretical framework. Paper presented at the Proceedings of the 38th Annual Hawaii International Conference on System Sciences.

Romano, N. C., \& Fjermestad, J. (2003). Electronic commerce customer relationship management: A research agenda. Information Technology and Management, 4(2-3), 233-258.

Ryals, L., \& Knox, S. (2001). Cross-functional issues in the implementation of relationship marketing through customer relationship management. European Management Journal, 19(5), 534-542.

Salameh, A., Ahmad, H., Zulhumadi, F., \& Abubakar, F. M. (2018). Relationships between system quality, service quality, and customer satisfaction. Journal of Systems and Information Technology, 20(1), 73-102.

Salameh, A., \& Hassan, S. B. (2015). Measuring service quality in m-commerce context: a conceptual model. International Journal of Scientific and Research Publications, 5(3), 1-9.

Sánchez-Garcia, J., Moliner-Tena, M. A., Callarisa-Fiol, L., \& Rodríguez-Artola, R. M. (2007). Relationship quality of an establishment and perceived value of a purchase. The Service Industries Journal, 27(2), 151-174.

Selnes, F. (1998). Antecedents and consequences of trust and satisfaction in buyer-seller relationships. European Journal of marketing, 32(3/4), 305-322.

Sheng, Y. (2002). A business model and framework for electronic customer relationship management. AMCIS 2002 Proceedings, 78.

Sivaraks, P., Krairit, D., \& Tang, J. C. (2011). Effects of e-CRM on customer-bank relationship quality and outcomes: The case of Thailand. The Journal of High Technology Management Research, 22(2), 141-157.

Suh, B., \& Han, I. (2003). The impact of customer trust and perception of security control on the acceptance of electronic commerce. International Journal of Electronic Commerce, 7(3), 135-161.

Tam, J. L., \& Wong, Y. (2001). Interactive selling: a dynamic framework for services. Journal of Services Marketing, 15(5), 379-396.

Tan, X., Yen, D. C., \& Fang, X. (2002). Internet integrated customer relationship management a key success factor for companies in the e-commerce arena. Journal of Computer Information Systems, 42(3), 77-86.

Usman, U. M. Z., Jalal, A. N., \& Musa, M. A. (2012). The impact of electronic customer relationship management on consumer's behavior. International Journal of Advances in Engineering \& Technology, 3(1), 500.

Wayland, R. E., \& Cole, P. M. (1997). Customer connections: new strategies for growth: Harvard Business Press.

Winer, R. S. (2001). A framework for customer relationship management. California management review, 43(4), 89-105.

$\mathrm{Xu}, \mathrm{M} .$, \& Walton, J. (2005). Gaining customer knowledge through analytical CRM. Industrial management \& data systems, 105(7), 955-971.

Ziaullah, M., Feng, Y., \& Akhter, S. N. (2014). Online retailing: relationship among e-tailing system quality, e-satisfaction, e-trust and customers commitment in China. International Journal of Economics, Commerce and Management, 2(10), $1-17$.

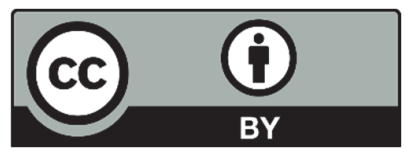

(C) 2020 by the authors; licensee Growing Science, Canada. This is an open access article distributed under the terms and conditions of the Creative Commons Attribution (CC-BY) license (http://creativecommons.org/licenses/by/4.0/). 